\title{
CONTACT PHYTOTOXICITY OF TRICLOPYR FORMULATIONS ON THREE PLANT SPECIES IN RELATION TO THEIR UPTAKE AND TRANSLOCATION
}

\author{
W.A. FORSTER, J.A. ZABKIEWICZ, R.J. MURRAY \\ and S.M. ZEDAKER ${ }^{1}$
}

\begin{abstract}
Plant Protection Chemistry, NZ Forest Research Inst, Rotorua, NZ
${ }^{I}$ Department of Forestry, Virginia Polytechnic and State University, Blacksburg, USA
\end{abstract}

\begin{abstract}
Three formulations of triclopyr, the ester, the amine, and amine plus organosilicone surfactant, were screened for contact phytotoxicity to the adaxial and abaxial surfaces of leaves of sweetgum, red maple and red oak, using a single concentration of herbicide and droplet size. Radiolabelled triclopyr was used to determine uptake and translocation. It was found that the amine formulation plus organosilicone surfactant, had uptake and translocation performance similar to that demonstrated with the ester formulation. Contact phytotoxicity symptoms appeared to be related to herbicide translocation.
\end{abstract}

Keywords: triclopyr, uptake, translocation, contact phytotoxicity, sweetgum, red maple, red oak

\section{INTRODUCTION}

Triclopyr ([(3,5,6-trichloro-2-pyridinyl)oxy]acetic acid) is an effective herbicide for hardwood control in the Northeastern and Southern USA and elsewhere in the world. The two commercial formulations, a triethylamine (TEA) salt (Garlon 3A) and a butoxyethyl ester ( Garlon 4 ), vary considerably in efficacy and environmental acceptability. In most applications, the ester formulation is more efficacious than the amine formulation, on an equal active ingredient basis. An alternative formulation, based on the amine derivative, could have the advantage of being less volatile or expressing lower contact phytotoxicity. In certain applications, contact phytotoxicity of herbicide formulations has been shown to isolate and confine the active ingredient (a.i.) physiologically to the site of penetration, thereby decreasing performance (McKinlayet al. 1972; Merritt 1980; Geiger and Bestman 1990). While uptake may be sufficient to control agronomic plants, translocation is the key to woody plant control due to the need to prevent resprouting (Cazell et al. 1990).

The present study examined contact phytotoxicity, uptake and translocation, of absorbed triclopyr formulations applied to the adaxial and abaxial leaf surfaces of three North American woody weed species, Quercus rubra (red oak), Acer rubrum (red maple) and Liquidamber styraciflua (sweetgum). The objectives were to determine if the uptake of the commercial amine formulation could be increased by the addition of a suitable adjuvant, and contact phytotoxicity reduced, to provide better efficacy against all three species.

\section{Plants}

\section{METHODS}

Red maple (Acer rubrum), red oak (Quercus rubra) and sweetgum (Liquidamber styraciflua) seedlings were grown outside in pots. Prior to the contact phytotoxicity study, plants were transferred to a controlled environment (light intensity 450-500 $\mathrm{mmol} / \mathrm{m}^{2} / \mathrm{s} ; 70 \%$ relative humidity; daylength of $11.5 \mathrm{~h}$ plus a $1 \%$ red light supplement for $0.5 \mathrm{~h}$ either side of the main photoperiod to provide dawn and dusk periods); the 
temperature was changed smoothly $\left(10^{\circ} \mathrm{C} / \mathrm{h}\right)$ between the night $\left(15^{\circ} \mathrm{C}\right)$ and day $\left(20^{\circ} \mathrm{C}\right)$ temperatures. All uptake and translocation studies were conducted under greenhouse conditions (daytime temperatures $27-35^{\circ} \mathrm{C}$, night time $14-18^{\circ} \mathrm{C}, 14 \mathrm{~h}$ daylength, 70 $100 \%$ relative humidity.)

\section{Formulations}

The three formulations used were: $3.59 \%$ Garlon 4 (DowElanco, triclopyr ester $61.6 \%$ a.i.), $5 \%$ Garlon $3 \mathrm{~A}$ (triclopyr amine, $44.4 \%$ a.i.) and $5 \%$ triclopyr triethylamine salt + sequestrant plus $0.2 \%$ Silwet L-77 (Witco Corp.). All formulations were at $1.6 \%$ acid equivalent (a.e.) of the active.

\section{Contact Phytotoxicity}

Treatments were applied as individual droplets ( $10 /$ leaf, $0.24 \mu l$ each) to the abaxial and adaxial surfaces of individual leaves (three plants, one leaf / plant / treatment) of all three plant species. Effects were observed at 2, 4, 6, 8 and 24 hours. Phytotoxicity was scored as nil (0), mild (1) and severe (2) to provide a numerical comparison.

\section{Foliar uptake}

Droplets of the triclopyr formulations $\left(0.24 \mu \mathrm{l} ; 20\right.$ drops / leaf) containing ${ }^{14} \mathrm{C}$ triclopyr $(3000-4000 \mathrm{dpm} / \mu \mathrm{l})$ were applied to the adaxial or abaxial surface of individual leaves on each of the three tree species. The quantity of $\left[{ }^{14} \mathrm{C}\right]$ chemical applied to leaves was determined by dispensing droplets (20) directly into scintillation vials (4 replicates). The leaves ( 5 replicates) were excised 24 hours after application and the treated surface washed with $2 \times 4 \mathrm{ml}$ water:ethanol (1+1 by volume; amine formulation) or $2 \times 4 \mathrm{ml}$ water:acetone (1:1 by volume; ester formulation) to recover unabsorbed $\left[{ }^{14} \mathrm{C}\right]$ triclopyr. The washings were taken up in $13 \mathrm{ml}$ ACS II scintillant (Amersham) and the $\left[{ }^{14} \mathrm{C}\right]$ quantified by liquid scintillation counting (Packard 4430). Foliar uptake was defined as $\left[{ }^{14} \mathrm{C}\right]$ triclopyr not recovered by washing the treated leaves and expressed as a percentage of total $\left[{ }^{14} \mathrm{C}\right]$ triclopyr applied. Control treatments using detached leaves, showed that losses of $\left[{ }^{14} \mathrm{C}\right]$ were negligible for most of the formulations used, and less than $10 \%$ for the remainder.

\section{Translocation}

Leaves sampled for foliar uptake determinations at $24 \mathrm{~h}$ were combusted (Harvey $\mathrm{OX} 300$ ) and the ${ }^{14} \mathrm{CO}_{2}$ trapped prior to liquid scintillation counting. Translocation (of absorbed triclopyr) was defined as the $\left[{ }^{14} \mathrm{C}\right]$ unaccounted for by the wash and oxidations, and was calculated as a percentage of the $\left[{ }^{14} \mathrm{C}\right]$ taken up into the leaf.

\section{Statistical analysis}

Analysis of variance was used to compare the treatments where significant effects were indicated by an F-test; means were compared using the LSD.

\section{RESULTS AND DISCUSSION}

The results presented are part of a much larger study to develop alternative triclopyr formulations for use on woody weed species and are used to illustrate the general trends and differences between the species and formulations (Table 1).

Uptake of ester (Garlon 4) was generally greater than the amine (Garlon 3A) in all species treatments. The addition of an organosilicone surfactant, Silwet L-77, increased uptake of the amine formulation, in all cases except one, to above that by the ester formulation. Hence it is possible to develop triclopyr amine formulations that have foliar uptake performance, with these three species, equivalent to or better than that obtained with the triclopyr ester formulation. Overall, uptake was generally greater from abaxial surfaces than from adaxial surfaces, in agreement with previous findings (Sargent and Blackman 1972; Sharma and Vanden Born 1970; King and Radosevich 1979). Analysis of variance of the three factor factorial, leaf surface $\mathrm{x}$ species $\mathrm{x}$ treatment, in relation to uptake, demonstrated that all three were highly significant $(\mathrm{P}<0.001)$.

Since herbicidal efficacy on woody weeds is largely dependent on good translocation of the active ingredient (Cazell et al. 1990), uptake alone is not a good indicator of formulation potential. In addition, it is known that there is considerable inter-species variation in susceptibility to triclopyr, part of which may be due to contact phytotoxicity by the specific formulation and its additives. Contact phytotoxicity is the damage caused to leaf tissue (including cell death) after spray droplet contact and is not directly 
attributable to the active ingredient alone. It can develop quite rapidly, so a series of observations are necessary to characterise its rate and severity. Contact phytotoxicity has been shown to isolate and confine the active ingredient physiologically to the site of penetration, thereby decreasing performance (Merritt 1980; Geiger and Bestman 1990; Prasad and Cadogan 1992). Since contact phytotoxicity may be due to high localised concentrations of formulant chemicals on a leaf surface, the addition of Silwet L-77 was intended to cause greater droplet spreading, reduce concentrations of products per unit leaf area, and also potentially improve uptake by stomatal infiltration on the abaxial surfaces.

TABLE 1: Contact phytotoxicity, uptake and translocation of triclopyr formulations into sweetgum, red maple and red oak foliage.

\begin{tabular}{|c|c|c|c|c|c|c|c|c|}
\hline \multirow{2}{*}{\multicolumn{2}{|c|}{$\begin{array}{l}\text { Formulation } \\
\text { Species/surface }\end{array}$}} & \multicolumn{5}{|c|}{ ContactPhytotoxicity } & \multirow{2}{*}{$\begin{array}{c}\text { Uptake } \\
(\%) \\
24 \mathrm{~h}\end{array}$} & \multirow{2}{*}{$\begin{array}{c}\text { Trans. } \\
\text { Abs. (\%) } \\
24 \mathrm{~h}\end{array}$} \\
\hline & & $2 \mathrm{~h}$ & $4 \mathrm{~h}$ & $6 \mathrm{~h}$ & $8 \mathrm{~h}$ & $24 \mathrm{~h}$ & & \\
\hline \multicolumn{9}{|c|}{ Ester } \\
\hline \multirow[t]{2}{*}{ SG } & Ad & $0^{\mathrm{e}}$ & $0^{\mathrm{e}}$ & $0^{\mathrm{e}}$ & $0^{\mathrm{e}}$ & $0^{\mathrm{e}}$ & $12^{\text {fg }}$ & $18^{\text {cde }}$ \\
\hline & $\mathrm{Ab}$ & $0^{\mathrm{e}}$ & $0^{\mathrm{e}}$ & $0.3^{\mathrm{de}}$ & $0.3^{\mathrm{de}}$ & $0.3^{\mathrm{de}}$ & $50^{\mathrm{cd}}$ & $6^{\text {defc }}$ \\
\hline \multirow[t]{2}{*}{ RM } & Ad & $0^{\mathrm{e}}$ & $0^{\mathrm{e}}$ & $0^{\mathrm{e}}$ & $0^{\mathrm{e}}$ & $0^{\mathrm{e}}$ & $42^{\mathrm{cd}}$ & $14^{\mathrm{de}}$ \\
\hline & $\mathrm{Ab}$ & $0^{\mathrm{e}}$ & $0^{\mathrm{e}}$ & $0.7^{\text {cde }}$ & $1^{\mathrm{bcd}}$ & $1.3^{\mathrm{abc}}$ & $86^{\mathrm{a}}$ & $5^{\mathrm{def}}$ \\
\hline \multirow[t]{2}{*}{$\mathrm{RO}$} & Ad & $0^{\mathrm{e}}$ & $0^{\mathrm{e}}$ & $1^{\mathrm{bcd}}$ & $1^{\mathrm{bcd}}$ & $1.7^{\mathrm{ab}}$ & $22^{\mathrm{fg}}$ & $4^{\mathrm{ef}}$ \\
\hline & $\mathrm{Ab}$ & $0.3^{\text {de }}$ & $0.7^{\text {cde }}$ & $1.3^{\mathrm{abc}}$ & $1.3^{\mathrm{abc}}$ & $1.3^{\mathrm{abc}}$ & $25^{\mathrm{ef}}$ & $1^{\mathrm{ef}}$ \\
\hline \multicolumn{9}{|c|}{ Amine } \\
\hline \multirow[t]{2}{*}{ SG } & Ad & $0^{\mathrm{e}}$ & $0^{\mathrm{e}}$ & $0^{\mathrm{e}}$ & $0^{\mathrm{e}}$ & $0^{\mathrm{e}}$ & $10^{\mathrm{g}}$ & $53^{\mathrm{a}}$ \\
\hline & $\mathrm{Ab}$ & $0^{\mathrm{e}}$ & $0^{\mathrm{e}}$ & $0.3^{\mathrm{de}}$ & $0.3^{\mathrm{de}}$ & $0.3^{\mathrm{de}}$ & $16^{\mathrm{fg}}$ & $40^{\mathrm{ab}}$ \\
\hline \multirow{2}{*}{$\mathrm{RM}$} & Ad & $0^{\mathrm{e}}$ & $0^{\mathrm{e}}$ & $0^{\mathrm{e}}$ & $0^{\mathrm{e}}$ & $0^{\mathrm{e}}$ & $19^{\text {fg }}$ & $22^{\mathrm{bcd}}$ \\
\hline & $\mathrm{Ab}$ & $0^{\mathrm{e}}$ & $0.7^{\text {cde }}$ & $1.3^{\mathrm{abc}}$ & $2^{\mathrm{a}}$ & $2^{\mathrm{a}}$ & $65^{\mathrm{b}}$ & $13^{\text {def }}$ \\
\hline \multirow[t]{2}{*}{$\mathrm{RO}$} & Ad & $0^{\mathrm{e}}$ & $0.3^{\mathrm{de}}$ & $0.7^{\text {cde }}$ & $0.7^{\text {cde }}$ & $1^{\mathrm{bcd}}$ & $11^{\mathrm{fg}}$ & $18^{\text {cde }}$ \\
\hline & $\mathrm{Ab}$ & $0.3^{\mathrm{de}}$ & $1.3^{\mathrm{abc}}$ & $1.7^{\mathrm{ab}}$ & $1.7^{\mathrm{ab}}$ & $1.7^{\mathrm{ab}}$ & $10^{\mathrm{g}}$ & $0^{f}$ \\
\hline \multicolumn{9}{|c|}{ Amine + L77 } \\
\hline \multirow[t]{2}{*}{ SG } & Ad & $0^{\mathrm{e}}$ & $0^{\mathrm{e}}$ & $0^{\mathrm{e}}$ & $0^{\mathrm{e}}$ & $0^{\mathrm{e}}$ & $15^{\mathrm{fg}}$ & $34^{\mathrm{bc}}$ \\
\hline & $\mathrm{Ab}$ & $0.3^{\mathrm{de}}$ & $1^{\mathrm{bcd}}$ & $1.3^{\mathrm{abc}}$ & $1.3^{\mathrm{abc}}$ & $1.7^{\mathrm{ab}}$ & $91^{\mathrm{a}}$ & $9^{\text {def }}$ \\
\hline \multirow[t]{2}{*}{$\mathrm{RM}$} & Ad & $0^{\mathrm{e}}$ & $0^{\mathrm{e}}$ & $0.3^{\text {de }}$ & $0.3^{\mathrm{de}}$ & $0.3^{\mathrm{de}}$ & $53^{\text {bcd }}$ & $15^{\text {de }}$ \\
\hline & $\mathrm{Ab}$ & $0^{\mathrm{e}}$ & $0^{\mathrm{e}}$ & $0.7^{\text {cde }}$ & $0.7^{\text {cde }}$ & $1.7^{\mathrm{ab}}$ & $55^{\mathrm{bc}}$ & $11^{\mathrm{def}}$ \\
\hline \multirow[t]{2}{*}{ RO } & Ad & $0^{\mathrm{e}}$ & $0^{\mathrm{e}}$ & $0^{\mathrm{e}}$ & $0^{\mathrm{e}}$ & $0.7^{\text {cde }}$ & $25^{\mathrm{ef}}$ & $6^{\text {def }}$ \\
\hline & $\mathrm{Ab}$ & $0^{\mathrm{e}}$ & $0^{\mathrm{e}}$ & $0.7^{\text {cde }}$ & $0.7^{\text {cde }}$ & $1.7^{\mathrm{ab}}$ & $39^{\mathrm{de}}$ & $5^{\text {def }}$ \\
\hline
\end{tabular}

Ester $=$ Garlon 4 ; Amine $=$ Garlon $3 \mathrm{~A} ;$ Amine $+\mathrm{L}-77=$ triclopyr amine + sequestrant + $0.2 \%$ Silwet L-77. Ad = Adaxial leaf surface $\mathrm{Ab}=$ Abaxial leaf surface

$\mathrm{SG}=$ sweetgum $\mathrm{RM}=$ red maple $\mathrm{RO}=$ red oak

Contact phytotoxicity means sharing common postscripts are not significantly different at $\mathrm{P}=0.05$ (LSD). Uptake means, or translocation of absorbed means within columns, sharing common postscripts are not significantly different at $\mathrm{P}=0.05$ (LSD).

Contact phytotoxicity to the abaxial leaf surface was always equal to or greater than phytotoxicity to the adaxial surface, for all three tree species (Table 1), suggesting that the lower leaf surfaces are much more susceptible to the herbicide formulations. The adaxial leaf surfaces of sweetgum and red maple show no significant contact phytotoxicity even after $24 \mathrm{~h}$, with any formulation. In contrast, the abaxial surfaces always showed necrosis, significantly in some cases. In the case of red oak, there was consistently higher phytotoxicity to both leaf surfaces, by all formulations, though of a lesser intensity on the adaxial surfaces. The abaxial surface of red oak shows the highest overall contact phytotoxicity to all formulations. Hence there are significant species differences in 
formulation sensitivity and therefore potential differences in efficacy. When $24 \mathrm{~h}$ data is considered, overall the addition of Silwet L-77 to the triclopyr amine formulation does not reduce the individual species' contact phytotoxicity responses. However, it is more appropriate to consider the rate at which contact phytotoxicity can develop, over the 24 h period. In that comparison, the addition of Silwet L-77 delayed and reduced phytotoxicity in red oak (the most susceptible species), and to a lesser extent in red maple, but increased the rate in sweetgum.

The relative amounts of herbicide translocated out of the treated leaf also appeared to relate to the rate at which contact phytotoxicity developed. Comparing the adaxial and abaxial leaf treatment results, within each species and formulation combination, there was in every case, lower translocation (of absorbed herbicide) where there was greater or earlier contact phytotoxicity development. There were also clear differences in translocation trends between the form of the herbicide $(\mathrm{P}<0.001$; the ester formulation showed lower translocation overall for all three species, possibly caused by the need for hydrolysis to the free acid first $)$ and there were clear species differences $(\mathrm{P}<0.001)$. Overall, red oak was the most susceptible species and had the lowest translocation results with all three formulations. If similar formulations are compared, then sweetgum with less contact phytotoxicity symptoms, shows very low translocation only with the triclopyr + Silwet L-77 treatment to the abaxial surface, where it also shows earlier and greatest contact phytotoxicity. Similar effects are observed with red maple.

\section{CONCLUSIONS}

The addition of Silwet L-77 to triclopyr triethylamine salt can improve uptake of the active ingredient into the three plant species, to equal or exceed that demonstrated by the ester formulation. The organosilicone surfactant is capable of reducing contact phytotoxicity in red oak, and possibly in red maple, but not in sweetgum. There is an apparent relationship between observed contact phytotoxicity and translocation of absorbed active ingredient, within species and formulations. There are clear species differences in relation to contact phytotoxicity, uptake and translocation, but not so clearcut between formulations.

\section{ACKNOWLEDGEMENT}

W.A. Forster wishes to acknowledge the support of Witco Corporation, OrganoSilicones Group and DowElanco during the fulfilment of her MS studies at Virginia Polytechnic and State University, Blacksburg.

\section{REFERENCES}

Cazell, J.T., Zedaker, S.M. and Seiler, J.R., 1990. Droplet size-concentration interactions in forest vegetation control. Proc. South. Weed Sci. Soc. 43: 215-219.

Geiger,D.R. andBestman,H.D., 1990. Self-limitation of herbicide mobility by phytotoxic action. Weed Sci. 38: 324-329.

King, M.G. and Radosevich, S.R., 1979. Tanoak (Lithocarpus densiflorus) leaf surface characteristics and absorption of triclopyr. Weed Sci. 27: 599-604.

McKinlay, K.S., Brandt, S.A., Morse, P. and Ashford, R., 1972. Droplet size and phytotoxicity of herbicides. Weed Sci. 20:450-452.

Merritt, C.R., 1980. The influence of application of variables on the biological performance of foliage-applied herbicides. Pp 35-43. In: Spraying Systems for the 1980's, J.O. Walker,(Ed), BCPC Monograph. No. 24, Croydon.

Prasad, R. and Cadogan, B.L., 1992. Influence of droplet size and density on phytotoxicity of three herbicides. Weed Tech. 6: 415-423.

Sargent, J.A. and Blackman, G.E., 1972. Studies on foliar penetration: IX. Patterns of penetration of 2,4-dichlorophenoxyacetic acid into the leaves of different species.J. Exp. Bot. 13: 348-368.

Sharma, M.P. and Vanden Born, W.H., 1970. Foliar penetration of picloram and 2,4-D in aspen and balsam poplar. Weed Sci. 18:57-63. 